The Journal of income and wealth, Vol. 34, No. 2, July-August, 2012

\title{
SOURCES OF AGRICULTURAL PRODUCTIVITY GROWTH IN ORISSA: A DISTRICT LEVEL ANALYSIS
}

\author{
A. Amarender Reddy \\ Author belongs to International Crops Research Institute for \\ Semi-arid Tropics (ICRISAT), E-mail: a.amarenderreddy@cgiar.org
}

The extent of India's regional disparities has been an issue since many decades, and this concern has been partly motivated by a desire to alleviate poverty (Datt and Ravallion, 1996). Agriculture remains an important feature of the economic, cultural and political landscape in India. Orissa is one of the poorest states in India. Over the last four decades, there has been stagnation in agriculture in Orissa. During the period 1991 to 2008 the growth rate of agriculture in Orissa is lower than allIndia. Orissa agriculture is highly concentrated in low productive and high waterconsuming paddy cultivation with little diversification towards pulses, oilseeds and other high value crops (HVCs: included Sugarcane, fruits and vegetables etc., which fetch higher net returns). It is also characterized by low use of fertilizer, energy and irrigation per unit area compared to other states. There is a need for increase in area under certified seed, irrigation and other productivity-enhancing inputs to increase farmers' income in all crops. There are perceptible regional disparities with the Coastal Plain having a distinct advantage in agricultural production compared to the Central Table Land region, Northern Plateau and Eastern Ghats regions as better initial socio-economic conditions in the Coastal plains in 1971 are having positive influence in growth in later years. Significant income gains are possible through crop diversification from paddy to pulses, oilseeds and HVCs in upland rain fed areas in kharif (rainy) season, if proper drainage, institutional and policy support is provided in Eastern Ghats and Northern Plateau of Orissa.

\section{Introduction}

The extent of India's regional disparities has been an issue since at least Independence, and this concern has been partly motivated by a desire to alleviate poverty (Datt and Ravallion, 1996). Agriculture remains an important feature of the economic, cultural and political landscape in India. Datt and Ravallion (1996) demonstrated that the poverty responds more to rural and agricultural economic growth than urban economic growth in developing countries. In the postGreen Revolution period, particularly in Asia, productivity growth has been sustained through increased input use and, more recently, through more efficient use of inputs ( Pingali and Heisey, 1999). India is divided into 28 states on administrative reasons. Regional perspectives of the development discourse were seen in the writings of Myrdal (1957) suggesting cumulative causation and core periphery models, which were elaborated upon by many other studies. They were of the view that regional imbalances were likely to widen in the absence of state intervention and narrow with politically necessary interventions, till finally the periphery becomes a beneficiary of the external economies of the core (Williamson 1965). However, after 50 years of planned development in India, many backward regions remain backward. Recently both inequalities among states and inequalities among districts/regions within states are growing across many states due to misguided policy (Audirac, 1997; Kurian,2000). 


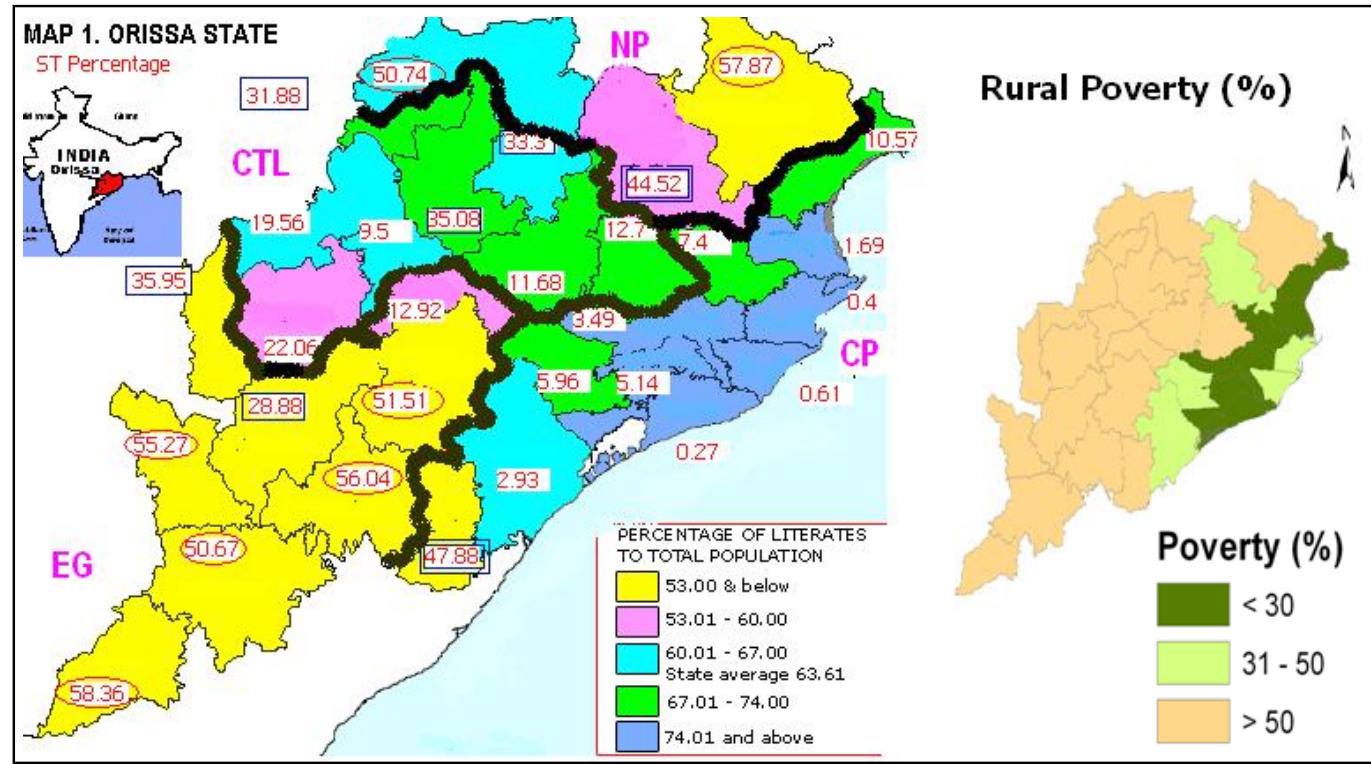

Orissa is one of the poorest states located in eastern India where about $85 \%$ of the population lives in rural areas (Map 1). Agriculture is the mainstay of the State's economy, providing employment to about $65 \%$ of the total work force, but it contributed only $22.5 \%$ to the Net State Domestic Production in 2009/10. More than $46 \%$ of the population lives below the poverty line in rural areas, as against $37 \%$ for all-India in 2004/5. Percent of small farmers (with less than 2 ha of land) is about $57 \%$ and landless laborers are about $36 \%$ of total households in rural Orissa (Mishra, 2009). In most of the development indicators, Orissa is backward compared to other states (Orissa Development Report, 2004) with large populations of scheduled tribes (22\%) and scheduled castes (17\%) who are socio-economically backward compared to other population. Orissa is 15.5 million hectare (mha) in geographical area, of which about 5.6 mha is cultivated land with a cropping intensity of $160 \%$, indicating $60 \%$ of the net sown area is cultivated with two crops per year. The net irrigated area is $2.0 \mathrm{mha}$ which is $35 \%$ of net cropped areas. Roughly $78 \%$ of the irrigation potential created is actually utilized as on 2010 . Still more than $80 \%$ of gross cropped area is occupied by food crops like food grains and oilseeds with subsistence agriculture. The state is characterized by under-utilisation of natural resources like land and water, with large area under forests and hence is suffering from low productivity.

\section{Historical background of regional disparities}

Orissa is divided in to four regions namely Coastal Plain (CP), Central Table Land (CTL), Northern Plateau (NP), and Eastern Ghats (EG) (Reddy, 2009c). The CP region is most prosperous region with an area of $26 \%$ of the state. The districts under this region are Baleswar, Cuttack, Puri and Ganjam. The average annual rainfall is about $1454 \mathrm{~mm}$. The soils of this region are mostly alluvial. This region is with the highest land productivity in the state. The 
CTL region covers an area of $24 \%$ of state comprising of districts Bolangir, Dhenkanal, and Sambalpur. The table land gradually rises from east to west and the elevation is within $300 \mathrm{~m}$ above Mean Sea Level (MSL). The average annual rainfall of the region is $1484 \mathrm{~mm}$. This region has light to medium textured red soils with low fertility. In addition, there are alluvial soils on hill slopes and river valleys with higher paddy productivity possible. The NP region is a plateau which covers about $18 \%$ of the area of the state. There are a number of hill ranges rising to an elevation of 600 to $900 \mathrm{~m}$ above MSL. This region is comprised of districts namely Mayurbhanj, Kendujhar and Sundargarh. The average annual rainfall is about $1610 \mathrm{~mm}$. The soils in the ridges and slopes are susceptible to erosion. These soils are acidic and have low fertility with low productivity. The EG region is one of the most backward region, and most of the well known KBK districts fall in this region which occupies the southern part of the state with $32 \%$ of the area of the state covering Koraput, Kalahandi and Phulbani districts. The average annual rainfall is about $1500 \mathrm{~mm}$. Soils have low to medium fertility. It is the poorest region with highest Scheduled Tribes (ST) \& Scheduled Caste (SC) population with lowest literacy rates (Map 1).

Since the formation of the Orissa state in 1936, the state government has given utmost priority exclusively to the $\mathrm{CP}$ ignoring more than half of the population of the state inhibited in about $73 \%$ of land area. Orissa is inhabited by more than $24 \%$ of tribal population concentrated mostly in EG and NP and CTL regions of the state. Due to the negligence of all successive state governments, the development of these three patches is far behind the CP by any parameter even though these regions are full of minerals and natural resources. The successive governments also concentrated on every developmental activity in and around the state capital Bhubaneswar (which is also located in CP) at the cost of neglected regions like EG, NP and CTL. Since last two decades, many developmental programs were introduced into lagging regions but still these regions are not able to catch up.

In the backdrop of high rural poverty, backward agriculture sector and distinct regional differences in Orissa agricultural sector, the paper explores (i) what is the productivity levels of Orissa compared to other competing states and all-India (ii) explore the reasons for backward agricultural sector, low growth rates in productivity and production of major crops like paddy, pulses and oilseeds during 1971-2008 (iii) examine the reasons for high concentration of area under low-productive kharif paddy and low-crop diversification to pulses, oilseeds and HVCs and (iv) Keeping high regional disparities in Orissa, the paper also examined regional variations in agricultural productivity and efficiency and what are the choices to increase production at district level?

\section{Data and Methodology}

Data

Inter-state comparison of agricultural sector with special emphasis on Orissa is done from 1971 to 2008 by using data from statistical abstracts of various states. The district level data of Orissa on agricultural production, other development indicators like markets, credit etc., was examined to know the regional/district level variation in agricultural sector. The ICRISAT district level database from 1971 to 2008 is used for the study. The analysis is done for the old undivided 13 districts for the purpose of showing changes in development indicators since 
1971, though 13 districts were divided into 30 districts in 1993. The whole study period from 1971 to 2008 is divided in to two periods (period-I: 1971-1990 representing pre-liberalisation of Indian economy; period-II: 1991-2008 representing post-liberalisation). The Gross Value of Agricultural Production (GVAP) at district level is measured at constant prices of 2004 by aggregating all crops production value in the district. Land and labour productivity per hectare is measured by using the GVAP for all the districts and regions.

\section{Battese and Coelli (1995) model}

The technical efficiency of a district is defined in terms of the ratio of the observed GVAP (output) to the corresponding frontier GVAP (output), conditional on the level of inputs in the district. Technical inefficiency is therefore defined as the difference between the district GVAP and the frontier level of GVAP. The district level efficiency is calculated by using Battese and Coelli (1995) stochastic production function model. A stochastic frontier production function is defined for panel data on districts, in which the non-negative technical inefficiency effects are assumed to be a function of district-specific variables and time. The inefficiency effects are assumed to be independently distributed as truncations of normal distributions with constant variance, but with means which are a linear function of observable variables. In this, the inefficiency effects $\left(\mathrm{U}_{\mathrm{i}}\right)$ are expressed as an explicit function of a vector of district-specific variables and a random error in a single regression, instead of two-stage regression. It may be expressed as:

$$
\mathrm{Y}_{\mathrm{it}}=\mathrm{x}_{\mathrm{it}} \beta+\left(\mathrm{V}_{\mathrm{it}}-\mathrm{U}_{\mathrm{it}}\right), \mathrm{i}=1, \ldots, \mathrm{N}, \mathrm{t}=1, \ldots, \mathrm{T},
$$

where $\quad Y_{\mathrm{i}}$ is the logarithm of the GVAP of the $\mathrm{i}$-th district;

$\mathrm{x}_{\mathrm{i}}$ is a $\mathrm{k} \mathrm{x} 1$ vector of logarithm of input quantities of the $\mathrm{i}$-th district;

$\beta$ is an vector of unknown parameters;

the $\mathrm{V}_{\mathrm{it}}$ are random variables which are assumed to be iid. $\mathrm{N}\left(0, \sigma_{\mathrm{v}}{ }^{2}\right)$, and independent of the $\mathrm{U}_{\mathrm{it}}$ which are non-negative random variables assumed to account for technical inefficiency in production and are assumed to be independently distributed as truncations at zero of the $\mathrm{N}\left(\mathrm{m}_{\mathrm{it}}, \sigma_{\mathrm{U}}^{2}\right)$ distribution; where:

$$
\mathrm{m}_{\mathrm{it}}=\mathrm{z}_{\mathrm{it}} \delta
$$

Where, $z_{\mathrm{it}}$ is a $\mathrm{X} 1$ vector of variables which may influence the efficiency of a district; and

$\delta$ is an $1 \mathrm{X} \mathrm{p}$ vector of parameters to be estimated.

The method replaces $\sigma_{\mathrm{V}}^{2}$ and $\sigma_{\mathrm{U}}^{2}$ with $\sigma^{2}=\sigma_{\mathrm{V}}^{2}+\sigma_{\mathrm{U}}^{2}$ and $\gamma=\sigma_{\mathrm{U}}{ }^{2} /\left(\sigma_{\mathrm{V}}{ }^{2}+\sigma_{\mathrm{U}}{ }^{2}\right)$. Parameter, $\gamma$, must lie between 0 and 1 . One can test whether any form of stochastic frontier production function is required at all by testing the significance of the $\gamma$ parameter. If the null hypothesis, that $\gamma$ equals zero, is accepted, this would indicate that $\sigma_{U}{ }^{2}$ is zero and hence that the $\mathrm{U}_{\mathrm{it}}$ term should be removed from the model, leaving a specification with parameters that can be consistently estimated using ordinary least squares. The authors used frontier-4.1 software for estimating the production function. 
The frontier 4.1 calculates predictions of individual district technical efficiencies from estimated stochastic production frontiers. The measures of technical efficiency relative to the production frontier defined as: $\mathrm{Eff}_{\mathrm{it}}=\mathrm{E}\left(\exp \left(\mathrm{Y}_{\mathrm{it}}\right) \mid \mathrm{U}_{\mathrm{it}}, \mathrm{X}_{\mathrm{it}}\right) / \mathrm{E}\left(\exp \left(\mathrm{Y}_{\mathrm{it}}\right) \mid \mathrm{U}_{\mathrm{it}}=0, \mathrm{X}_{\mathrm{it}}\right)$, where $\mathrm{Y}_{\mathrm{it}}$ is the GVAP of the $\mathrm{i}$-th district in $\mathrm{t}$-th period. In the case of a production frontier, $\mathrm{Eff}_{\mathrm{it}}$ will take a value between 0 and 1 . The efficiency measures can be shown to be defined as $\exp \left(-\mathrm{U}_{\mathrm{it}}\right)$ as dependent variable is in $\log$ form.

District level production efficiency is estimated by using log of district level GVAP as dependent variable in Battese and Coelli model. The district level data set for 13 districts from 1971 to 2008 ( 37 years) is used to construct the model. The independent variables considered in the model are (i) Gross Cropped Area (1000 ha), (ii) Gross Irrigated Area (1000 ha), (iii) Rural Agricultural Workers (1000 nos), (iv) Total adult male buffalo and cattle population, (v) Tractor (number of tractors), (vi) Fertilizer use (tons), (vii) Area under HYVs (1000 ha) and (viii) Time (years). The variables which may influence the efficiency of a district are (i) Loans (Rs. 1000), (ii) Rainfall (mm), (iii) Rural literates (1000 nos), (iv)Length of roads (km), (v) Pulses area (1000 ha), (vi) Oilseeds area (1000 ha), (vii) HVCs area (1000 ha), (viii) Central Table Land dummy, (ix) Eastern Ghat dummy and (x) Coastal Plain dummy. All variables are in log-form except regional dummies and time.

The stochastic production function, defined in equation (1), is a linearised approximation of a Cobb-Douglas production function; hence the regression coefficients are direct estimates of elasticity of GVAP for respective input. Using the elasticities of GVAP $\left(\mathrm{Y}_{\mathrm{it}}\right)$ with respect to area under pulses, oilseeds and HVCs(sugarcane, cotton, fruits and vegetables and spices) one can estimate the Value of Marginal Product (VMP) per one unit ( per ha) shift in area from paddy to pulses, oilseeds and HVCs.

$$
\begin{gathered}
\mathrm{VMP} / \text { ha of pulses area }=\beta_{\text {(pulses area) }} *(\text { Y/pulses area }) \\
\mathrm{VMP} / \text { ha of oilseed area }=\beta_{\text {(oil seed area) }} *(\text { Y/oilseed area }) \\
\mathrm{VMP} / \text { ha of HVCs area }=\beta_{(\mathrm{HVCs} \text { area) }} *(\mathrm{Y} / \mathrm{HVCs} \text { area })
\end{gathered}
$$

\section{Results}

\section{Stagnation in agricultural production and productivity}

Out of the Gross Cropped Area (GCA) of 9.0 mha in 2008, 77 per cent is under food grains. Thus, only 23 per cent of the GCA was under non-food grains, which includes oilseeds, fibre crops, and HVCs. Paddy occupies about 50 per cent of GCA, followed by pulses (22\%), oilseeds (9\%) and HVCs (13\%). Area under paddy decreased from 66 per cent in 1971 to 46 per cent in 1991, then again increased to 50 per cent by 2008, while area under oilseeds increased from 4.9 per cent in 1971 to 12 per cent in 1991, then declined to 9 per cent, and pulses area increased from 12.5 per cent in 1971 to 22 per cent in 2008 (Table 1). Area under HVCs increased from 8.1 per cent in 1971 to 13 per cent of GCA in 2008. Cropping intensity increased from 133 per cent in 1971 to 158 per cent in 2008. 
Table 1

\section{Per cent area under different crops in 1971, 1991 and 2008 in Orissa}

\begin{tabular}{lrrr}
\hline Crop & 1971 & 1991 & 2008 \\
\hline Paddy & 66.1 & 45.9 & 50.0 \\
Other Cereals & 6.3 & 5.8 & 5.0 \\
Pulses & 12.5 & 22.2 & 22.0 \\
Food grains (cereals plus pulses) & 84.9 & 73.9 & 77.0 \\
Oil Seeds & 4.9 & 12.1 & 9.0 \\
Food Crops (cereals plus oilseeds) & 89.8 & 86.0 & 86.0 \\
Fibre crops (jute and mesta) & 1.2 & 0.9 & 1.0 \\
HVCs (Sugarcane, vegetables, fruits, spices, cotton) & 8.1 & 12.4 & 13.0 \\
All Crops & 100 & 100 & 100 \\
GCA (m ha) & 5.6 & 6.3 & 9.0 \\
Cropping Intensity (\%) & 133 & 141 & 158 \\
\hline
\end{tabular}

Source: Orissa Agricultural Statistics (2011), various issues

Over all, food grain production increased from 5.6 million tons (mt) during Triennium

Ending average (TE) 1973 to $7.4 \mathrm{mt}$ in TE 2008, entirely contributed by increase in paddy production from $4.2 \mathrm{mt}$ in TE 1973 to $6.0 \mathrm{mt}$ in TE 2008. Pulses production stagnant at 0.8 $\mathrm{mt}$ and oilseed production is also stagnant at about 0.5 to $0.6 \mathrm{mt}$ (Table 2). This indicated the dominance and increased importance of paddy in the state. However, productivity of paddy still low, increased slowly from $964 \mathrm{~kg} / \mathrm{ha}$ to $1335 \mathrm{~kg} / \mathrm{ha}$ in Orissa, whereas it increased from $1312 \mathrm{~kg} / \mathrm{ha}$ in period-I to $1940 \mathrm{~kg} / \mathrm{ha}$ in period-II for all-India. Productivity of pulses declined (from $503 \mathrm{~kg} / \mathrm{ha}$ to $441 \mathrm{~kg} / \mathrm{ha}$ ) and oilseeds stagnant (from $683 \mathrm{~kg} / \mathrm{ha}$ to $669 \mathrm{~kg} / \mathrm{ha}$ ) between two periods. The productivity of all major crops was lower in Orissa than all-India in both the periods. During period-I, growth in production of food grains is lower in Orissa compared to all-India, while growth in pulses and oilseeds is higher. During period-II, the growth rates for all the crops (food grains; including paddy, pulses and oilseeds) in production, area

Table 2

Trends in Area, Production and Productivity of Major Crops

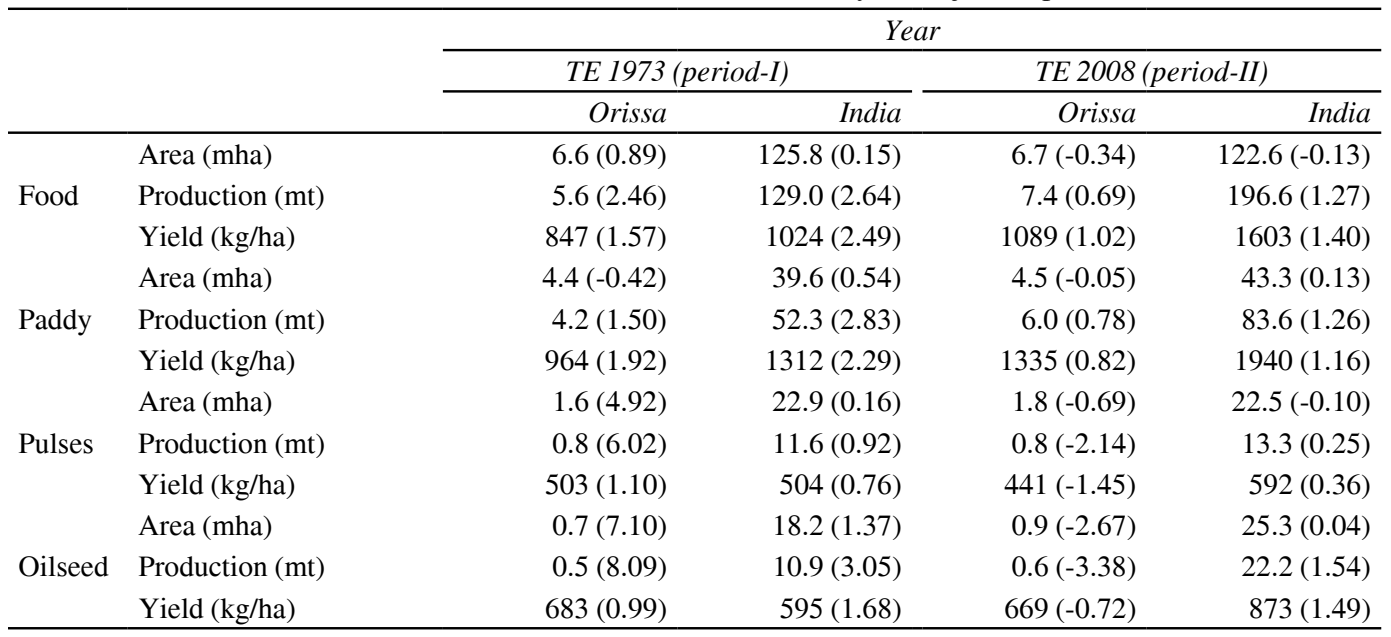

Source: Statistical Abstracts, Orissa and India; Note: figures in parentheses are annual compound growth rates $(\%)$ in period-I and period-II 
and productivity are lower (and reduced) in Orissa than all-India. This shows the decline or stagnation in Orissa agricultural sector during both the periods, but it is alarming during recent period. The over emphasis on paddy at the cost of pulses, oilseeds and other HVCs resulted in stagnation in productivity of the later crops during period-II (Reddy, 2004, Reddy 2009a, Reddy et al., 2011).

\section{Comparison of Orissa Agriculture with Other States}

The comparative status of Orissa in agricultural sector for the TE 2008 is presented in table 3. The productivity of food grains in Orissa was much lower $(1348 \mathrm{~kg} / \mathrm{ha})$ than the neighboring states like West Bengal $(2332 \mathrm{~kg} / \mathrm{ha})$ and Andhra Pradesh $(2120 \mathrm{~kg} / \mathrm{ha})$ was equivalent to less developed state like Madhya Pradesh $(1177 \mathrm{~kg} / \mathrm{ha})$. The average productivity of paddy (single most important crop in Orissa) is only $1348 \mathrm{~kg} / \mathrm{ha}$ compared to the all-India average of $2046 \mathrm{~kg} / \mathrm{ha}$. The reason for low productivity of paddy in the state is that, it was cultivated mostly in kharif (rainy) season (about $93 \%$ of total paddy area is from kharif season) which is characterized by low and uncertain productivity as most of the area is rain-fed. Development indicators like fertilizer consumption (just $43.8 \mathrm{~kg} / \mathrm{ha}$ in Orissa compared to $136 \mathrm{~kg} / \mathrm{ha}$ in West Bengal and $155.5 \mathrm{~kg} / \mathrm{ha}$ in Andhra Pradesh), Credit-Deposit ratio (40\% in Orissa as against $51 \%$ for All-India) and number of bank branches $/ 1000 \mathrm{~km}^{2}$ (3.9 in Orissa as against 6 for AllIndia) in Orissa were one of the lowest in India (Reddy 2006). Irrigated area is just $27.5 \%$ of total cropped area in Orissa as against national average of $38.7 \%$, even though the state had higher irrigation potential with many perennial rivers with annual rainfall of $1400 \mathrm{~mm}$ against national average of $1100 \mathrm{~mm}$. Even though gross irrigated area is less, most of the irrigated area is occupied by paddy (65\% of GIA), followed by vegetables (17\% of GIA), pulses (7\% of GIA) and oilseeds (5\% of GIA) (Orissa Development Report, 2004). As a result of all these factors, agricultural GDP/ha is just Rs 11839 /ha in Orissa as against Rs 39872/ha in West Bengal and Rs 21443/ha in Andhra Pradesh in TE 2008. Overall, it appears that low input use per ha (including fertilizer, power etc) and high concentration in paddy, low priority given to pulses and oilseeds characterize the Orissa agricultural sector. There is a need to increase area under irrigation in pulses and oilseeds, by reducing area under high water consuming crops like paddy in both kharif and rabi seasons.

Table 3

Inter-state Comparison of Indicators of Agricultural Development TE 2008

\begin{tabular}{lrrrrrrr}
\hline State & Orissa & $\begin{array}{r}\text { West } \\
\text { Bengal }\end{array}$ & $\begin{array}{r}\text { Andhra } \\
\text { Pradesh }\end{array}$ & $\begin{array}{r}\text { Madhya } \\
\text { Pradesh }\end{array}$ & Punjab & Haryana & India \\
\hline Productivity of food grains (kg/ha) & 1348 & 2332 & 2120 & 1177 & 3964 & 2862 & 1717 \\
\% irrigated area to GCA & 27.5 & 27.5 & 43.1 & 25.8 & 94.1 & 78.8 & 38.7 \\
Credit-Deposit Ratio (\%) & 39.8 & 45.2 & 63.8 & 49.2 & 39.1 & 41.4 & 50.8 \\
Bank branches/1000 km ${ }^{2}$ & 3.9 & 8.3 & 4.7 & 3 & 5.9 & 4.2 & 6.0 \\
Agril. GDP (Rs./ha) & 11839 & 39872 & 21443 & 10881 & 41534 & 33741 & 22907 \\
Poverty (\%) & 48 & 31.9 & 11.1 & 37.1 & 6.4 & 8.3 & 20.6 \\
\hline
\end{tabular}

Source: Annual Statistical Abstracts (2011) of Various States

In the last two decades, the use of modern inputs is like fertilizer increased from $20 \mathrm{~kg} /$ ha to $53 \mathrm{~kg} / \mathrm{ha}$ in Orissa, as against from $67.5 \mathrm{~kg} / \mathrm{ha}$ to $115 \mathrm{~kg} / \mathrm{ha}$ for India (Table 4). Share of agricultural sector in total power consumption in Orissa decreased from very lower level of 
$4.7 \%$ to just about $1.4 \%$ from 1991 to 2007 , while, share of agricultural sector for all-India is hovering around $23 \%$ to $26 \%$ during the same period. In absolute terms also power consumption decreased from 229 million units to 130 million units. It indicates that the agriculture in Orissa is trapped in low-input low-output vicious cycle. Seed is most important input in increasing agricultural productivity. The Seed Replacement Ratio (SRR) is defined as the \% of area sowed with new seed every year. It is much lower in Orissa than all-India for many crops including main crop paddy (Table 5). To enhance agricultural growth, we need to increase application of inputs like seed, fertilizer, power consumption and irrigated area. The lower SRR is also due to high logistic costs in seed production and distribution in the remote villages with low infrastructure and lack of farmer's ability to pay for high priced seed (Reddy 2004) resulted in reluctance of private seed companies in the seed distribution. Further, an analysis of trends in the number of operational holdings and area operated reveals that the number of operational holdings with less than 2 ha (small and marginal farmers) increased from 80.3\% in 1972 to $83.8 \%$ in 2005 . Reduced farm size is a hindrance to adopt high-input incentive seed-fertilizerirrigation agricultural technology (Orissa Development Report, 2004).

Table 4

Power Consumption for Agriculture as \% of Total Consumption

\begin{tabular}{|c|c|c|c|c|c|}
\hline \multirow[t]{2}{*}{ Year } & \multicolumn{2}{|c|}{$\begin{array}{l}\text { Power consumption } \\
\text { for agriculture as \% } \\
\text { of total consumption }\end{array}$} & \multirow{2}{*}{$\begin{array}{r}\text { power consumption } \\
\text { (million units) for } \\
\text { agriculture }\end{array}$} & \multicolumn{2}{|c|}{$\begin{array}{l}\text { Fertilizer consumption } \\
\qquad(\mathrm{kg} / \mathrm{ha})\end{array}$} \\
\hline & Orissa & India & & Orissa & India \\
\hline 1991 & 4.7 & 26.4 & 229 & 20.0 & 67.6 \\
\hline 2001 & 3.1 & 26.8 & 186 & 41.0 & 90.1 \\
\hline 2007 & 1.4 & 22.9 & 130 & 53.0 & 115.3 \\
\hline
\end{tabular}

Source: Statistical Abstracts, Orissa and India

Table 5

Seed Replacement Rate (\%) in TE 2008

\begin{tabular}{lrrrrrrr}
\hline State & Paddy & Maize & Urd & Moong & Arhar & Mustard & Cotton \\
\hline Orissa & 6.0 & 1.4 & 1.3 & 1.3 & 1.6 & 17.5 & 9.0 \\
India & 24.2 & 34.4 & 16.4 & 12.6 & 10.4 & 56.7 & 21.6 \\
\hline
\end{tabular}

Source: Statistical Abstracts, Orissa and India

\section{Efficiency estimates}

The results of Battese and Coelli (1995) model applied to district level data revealed that, GCA, cattle population and number of rural agricultural workers has positive and significant influence on district level GVAP (Table 6). This indicates that the Orissa agricultural sector productivity is still heavily dependent on traditional inputs like GCA, human labour and bullock labour. Another important variable 'time' is not significant, which infer that there is no significant technological progress during the past 37 years. As expected, inefficiency of district crop production is negatively affected by rainfall, number of rural literates, and area under pulses, oilseeds and HVCs. In other wards, efficiency at district level is positively and significantly influenced by rainfall, rural literacy, and area under pulses, oilseeds and HVCs. Among regional dummies, EG dummy influenced inefficiency positively, in other words districts of EG are most likely to have low efficiency compared to NP (which is taken as a reference category). 
Table 6

Regression Results (Battese and Coelli 1995 model) (Dependent variable: $\log$ (GVAP of districts in Rs.10000)

\begin{tabular}{|c|c|c|c|}
\hline Variables & $B$ & $t$-ratio & Mean \\
\hline Constant & 9.80 & 0.69 & \\
\hline Gross Cropped Area (1000 ha) & $0.69 *$ & 6.90 & 661 \\
\hline Gross Irrigated Area (1000 ha) & -0.01 & -0.23 & 199 \\
\hline Rural Agricultural Workers (1000 nos) & $0.10^{*}$ & 1.84 & 313 \\
\hline Total adult male buffalo and cattle population & $0.10^{*}$ & 1.85 & 1016 \\
\hline Tractor (number of tractors) & 0.02 & 1.51 & 59 \\
\hline Fertilizer use (tons) & 0.01 & 0.35 & 14723 \\
\hline Area under HYVs (1000 ha) & 0.02 & 0.67 & 162 \\
\hline Time (years) & 0.001 & 0.11 & \\
\hline \multicolumn{4}{|l|}{ Inefficiency effects } \\
\hline Constant & 4.85 & 0.34 & \\
\hline Loans (Rs. 1000) & -0.02 & -1.29 & 75784 \\
\hline Rainfall (mm) & $-0.15^{*}$ & -3.80 & 1417 \\
\hline Rural literates (1000 nos) & $-0.11 *$ & -2.62 & 748 \\
\hline Length of roads $(\mathrm{km})$ & -0.04 & -1.41 & 10661 \\
\hline Pulses area (1000 ha) & $-0.19^{*}$ & -5.25 & 137 \\
\hline Oilseeds area (1000 ha) & $-0.12 *$ & -5.08 & 60 \\
\hline HVCs area (1000 ha) & $-0.06^{*}$ & -2.89 & 7 \\
\hline Central Table Land dummy & -0.07 & -1.40 & 0 \\
\hline Eastern Ghat dummy & $0.25^{*}$ & 5.73 & 0 \\
\hline Coastal Plain dummy & 0.08 & 1.67 & 0 \\
\hline sigma-squared & 0.04 & 15.03 & \\
\hline gamma & 0.31 & 0.03 & \\
\hline
\end{tabular}

Note: all variables are in log-form except regional dummies and time

Log likelihood function $=107.1 ;$ LR test of the one-sided error $=143.7$

\section{Growing inter-regional differences in agricultural development}

Region-wise production trends of major crops are given in table 7. CP was the largest producer of paddy, followed by CTL, EG and NP, but the productivity is higher in CTL (1799 kg/ha), followed by CP (1667 kg/ha), NP (1464 kg/ha) and the least recorded in EG region $(1402 \mathrm{~kg} /$ ha). While, in case of pulses CP and EG were large producers, in case of productivity all regions reported less than $600 \mathrm{~kg} / \mathrm{ha}$ which was quite low compared to national average. In case of oilseeds, CP and CTL are large producers with higher productivity. Overall, the productivity, area and production of paddy and oilseeds are much higher in CP and CTL compared to NP and EG regions, while production of pulses is more in CP and EG but with very low productivity. Orissa is one of the most disaster prone states in the country, every alternate year there is high probability of either drought or flood. The Orissa agricultural production is characterized by high volatility as the $\%$ irrigated area is less (table 8 ). The instability is higher in oilseeds production (coefficient of variation is $107 \%$ ) followed by pulses $(56 \%)$ and the least in paddy $(55 \%)$. While instability in area is also higher in oilseeds ( $80 \%)$ followed by pulses (54\%) and paddy (35\%), but instability in productivity was higher in oilseeds (48\%) followed by paddy (35\%) and the least in pulses (14\%). The less instability in productivity of pulses indicates their tolerance to biotic and abiotic stresses compared to paddy and oilseeds. One interesting 
feature is that instability increased in oilseeds and paddy increased in recent period. Overall, the instability is higher in EG for all the major crops followed by NP and CTL and the least in CP.

Table 7

Region Wise Trends in Area, Production and Productivity of Food Crops TE 2008

\begin{tabular}{|c|c|c|c|c|c|c|c|c|c|}
\hline \multirow[t]{2}{*}{ Region } & \multicolumn{5}{|c|}{ Production $(1000 t)$} & \multicolumn{4}{|c|}{ Productivity $(\mathrm{kg} / \mathrm{ha})$} \\
\hline & Paddy & Pulses & Oilseeds & $\begin{array}{r}\text { Sugar- } \\
\text { cane }\end{array}$ & $\begin{array}{l}\text { Fruits and } \\
\text { Vegetables }\end{array}$ & Paddy & Pulses & Oilseeds & Sugarcane \\
\hline $\mathrm{CP}$ & $\begin{array}{r}8168 \\
(72)\end{array}$ & $\begin{array}{l}986 \\
(30)\end{array}$ & $\begin{array}{r}721 \\
(190)\end{array}$ & $\begin{array}{r}330 \\
(19)\end{array}$ & $\begin{array}{r}2836 \\
(497)\end{array}$ & $\begin{array}{r}1667 \\
(90)\end{array}$ & $\begin{array}{r}429 \\
(-13)\end{array}$ & $\begin{array}{r}1197 \\
(21)\end{array}$ & $\begin{array}{r}6634 \\
(-2)\end{array}$ \\
\hline CTL & $\begin{array}{r}6096 \\
(87)\end{array}$ & $\begin{array}{r}575 \\
(148)\end{array}$ & $\begin{array}{r}509 \\
(111)\end{array}$ & $\begin{array}{r}119 \\
(-26)\end{array}$ & $\begin{array}{l}1446 \\
(545)\end{array}$ & $\begin{array}{r}1799 \\
(99)\end{array}$ & $\begin{array}{r}384 \\
(-29)\end{array}$ & $\begin{array}{r}629 \\
(-29)\end{array}$ & $\begin{array}{r}7183 \\
(14)\end{array}$ \\
\hline NP & $\begin{array}{r}3268 \\
(79)\end{array}$ & $\begin{array}{r}258 \\
(155)\end{array}$ & $\begin{array}{r}126 \\
(36)\end{array}$ & $\begin{array}{r}7 \\
(-74)\end{array}$ & $\begin{array}{r}1767 \\
(718)\end{array}$ & $\begin{array}{r}1464 \\
(88)\end{array}$ & $\begin{array}{r}459 \\
(0)\end{array}$ & $\begin{array}{r}412 \\
(-32)\end{array}$ & $\begin{array}{r}5632 \\
(-4)\end{array}$ \\
\hline EG & $\begin{array}{l}4015 \\
(110)\end{array}$ & $\begin{array}{r}750 \\
(184)\end{array}$ & $\begin{array}{r}470 \\
(121)\end{array}$ & $\begin{array}{r}351 \\
(117)\end{array}$ & $\begin{array}{r}1243 \\
(748)\end{array}$ & $\begin{array}{r}1402 \\
(69)\end{array}$ & $\begin{array}{l}516 \\
(13)\end{array}$ & $\begin{array}{l}601 \\
(17)\end{array}$ & $\begin{array}{r}7325 \\
(44)\end{array}$ \\
\hline Orissa & $\begin{array}{r}21546 \\
(83)\end{array}$ & $\begin{array}{r}2568 \\
(90)\end{array}$ & $\begin{array}{l}1827 \\
(130)\end{array}$ & $\begin{array}{l}806 \\
(29)\end{array}$ & $\begin{array}{r}7292 \\
(587)\end{array}$ & $\begin{array}{r}1610 \\
(87)\end{array}$ & $\begin{array}{r}442 \\
(-10)\end{array}$ & $\begin{array}{r}730 \\
(0)\end{array}$ & $\begin{array}{r}6990 \\
(15)\end{array}$ \\
\hline
\end{tabular}

Note: figures in the parenthesis are \% increase from TE 1973; region wise productivity figures were not available

Table 8

Coefficient of Variation (\%) of Area, Production and Productivity of Major Crops in Orissa

\begin{tabular}{|c|c|c|c|c|c|c|c|c|c|c|}
\hline \multirow[t]{2}{*}{ Region } & \multirow[t]{2}{*}{ Period } & \multicolumn{3}{|c|}{ Paddy } & \multicolumn{3}{|c|}{ Pulses } & \multicolumn{3}{|c|}{ Oilseeds } \\
\hline & & Production & Area & Yield & Production & Area & Yield & Production & Area & Yield \\
\hline \multirow[t]{2}{*}{$\mathrm{CP}$} & $1971-1990$ & 38 & 29 & 29 & 46 & 41 & 12 & 91 & 60 & 33 \\
\hline & $1991-2008$ & 34 & 24 & 41 & 34 & 29 & 12 & 52 & 37 & 75 \\
\hline \multirow[t]{2}{*}{ CTL } & $1971-1990$ & 44 & 31 & 30 & 59 & 50 & 10 & 74 & 65 & 25 \\
\hline & $1991-2008$ & 53 & 35 & 28 & 31 & 25 & 9 & 92 & 79 & 105 \\
\hline \multirow[t]{2}{*}{ NP } & $1971-1990$ & 36 & 23 & 20 & 46 & 40 & 18 & 58 & 45 & 26 \\
\hline & $1991-2008$ & 51 & 32 & 92 & 12 & 9 & 5 & 66 & 45 & 93 \\
\hline \multirow[t]{2}{*}{ EG } & $1971-1990$ & 57 & 48 & 27 & 60 & 50 & 21 & 58 & 40 & 26 \\
\hline & 1991-2008 & 59 & 47 & 34 & 55 & 48 & 21 & 84 & 65 & 102 \\
\hline \multirow[t]{2}{*}{ Orissa } & $1971-1990$ & 51 & 40 & 26 & 74 & 73 & 6 & 108 & 70 & 37 \\
\hline & $1991-2008$ & 55 & 35 & 35 & 56 & 54 & 14 & 107 & 80 & 48 \\
\hline
\end{tabular}

Source: Statistical Abstracts, Orissa

Per cent share of each crop in GVAP at constant prices of 2004/05 is given in table 9. The share of paddy in GVAP decreased from 56 per cent in TE 1973 to 54 per cent in TE 2008. Share of pulses stagnant at 13 per cent, while share of oilseeds increased from 7 per cent to 9 per cent and share of fruits and vegetables increased at faster rate from 6 per cent to 10 per cent. In terms of contribution of regions to GVAP, share of CP region decreased from 42 per cent to 38 per cent, share of EG increased from 19 per cent to 22 per cent, while share of CTL and NP regions are stagnant at 26 per cent and 14 per cent respectively. Indicating catching up of EG with CP. Share of paddy is higher in both NP and CTL, but slightly decreased in TE 2007. In case of pulses, share of EG and CP is higher in both the periods. While in case of oilseeds, EG and CTL dominate in both the periods. Share of fruits and vegetables is about 10 per cent of state GVAP, and its share is higher in NP with 12 per cent. 
Table 9

Region wise \% Share of Major Crop Groups in GVAP in TE 1973 and TE 2008 at Constant Price of 2004/5

\begin{tabular}{|c|c|c|c|c|c|c|c|}
\hline Region & Paddy & Pulses & Oilseeds & Sugarcane & $\begin{array}{c}\text { Fruits and } \\
\text { Vegetables }\end{array}$ & Rs. Million & $\begin{array}{r}\% \text { to state } \\
\text { GVAP }\end{array}$ \\
\hline \multicolumn{8}{|c|}{ TE 1973} \\
\hline $\mathrm{CP}$ & 54 & 26 & 8 & 0.71 & 7 & $50456(100)$ & 42 \\
\hline CTL & 62 & 13 & 13 & 0.68 & 6 & $30398(100)$ & 25 \\
\hline NP & 67 & 11 & 10 & 0.21 & 7 & $15624(100)$ & 13 \\
\hline $\mathrm{EG}$ & 46 & 19 & 15 & 0.88 & 7 & $23778(100)$ & 20 \\
\hline Orissa & 56 & 19 & 11 & 0.67 & 7 & $120256(100)$ & 100 \\
\hline \multicolumn{8}{|c|}{ TE 2008} \\
\hline $\mathrm{CP}$ & 54 & 20 & 14 & 0.49 & 10 & $86562(100)$ & 37 \\
\hline CTL & 60 & 17 & 15 & 0.26 & 8 & $58354(100)$ & 25 \\
\hline NP & 63 & 15 & 7 & 0.03 & 13 & $30039(100)$ & 13 \\
\hline EG & 41 & 23 & 14 & 0.81 & 10 & $56059(100)$ & 24 \\
\hline Orissa & 54 & 19 & 13 & 0.45 & 10 & $231013(100)$ & 100 \\
\hline
\end{tabular}

Source: Statistical Abstracts, Orissa

Table 10 shows that during TE 2008, cropping intensity is higher in CP followed by CTL, EG and the least in NP. In the same way CP $(53.4 \mathrm{~kg} / \mathrm{ha})$ and CTL $(48.5 \mathrm{~kg} / \mathrm{ha})$ regions ranked the highest in fertilizer consumption, while NP region ranked the lowest with $30 \mathrm{~kg} / \mathrm{ha}$. In credit (Rs/ ha of GCA), CTL region ranked the highest, while EG ranked the least. So credit uptake is higher in developed region than less developed region. CP ranked the highest and EG ranked least in rural literacy. The above all development indicators show that the $\mathrm{CP}$ is the developed region and the EGs are the least developed region, while NP and CTL fall in the middle.

Table 10

Region Wise Indices of Agriculture in TE 2008

\begin{tabular}{|c|c|c|c|c|c|c|c|}
\hline Region & $\begin{array}{r}\text { Cropping } \\
\text { intensity } \\
(\%)\end{array}$ & $\begin{array}{l}\text { Fertilizer/ } \\
h a(k g / h a)\end{array}$ & $\begin{array}{r}\text { Rainfall } \\
(\mathrm{mm})\end{array}$ & $\begin{array}{r}\% \text { irrigated } \\
\text { area }\end{array}$ & $\begin{array}{r}\text { Credit (Rs./ } \\
h a)\end{array}$ & $\begin{array}{r}\text { average } \\
\text { farm } \\
\text { size }(h a)\end{array}$ & $\begin{array}{l}\text { \% rural } \\
\text { Literacy }\end{array}$ \\
\hline $\mathrm{CP}$ & 176 & 53 & 1454 & 45 & 3855 & 1.1 & 46 \\
\hline CTL & 158 & 49 & 1484 & 32 & 3023 & 1.5 & 37 \\
\hline NP & 134 & 30 & 1610 & 27 & 2128 & 1.4 & 33 \\
\hline EG & 157 & 38 & 1500 & 30 & 1432 & 1.7 & 22 \\
\hline Orissa & 159 & 45 & 1500 & 35 & 2783 & 1.3 & 35 \\
\hline
\end{tabular}

Source: Statistical Abstracts, Orissa

Inter regional differences in land \& labour productivity and efficiency

Land and labour productivity are two important indicators of performance of agricultural sector in region. The land and labour productivity indices along with efficiency indices measured from Battese and Coelli (1995) model are given in table 11. Mean efficiency in the state is 37\%, with average land productivity of Rs.6872/ha and average labour productivity of Rs. 13779/ agricultural worker in 1991-2008. The highest efficiency was reported in CTL (46\%) and CP (43\%) followed by EG (32\%) and the least in NP (25\%). In similar lines, the land productivity is higher in CTL (Rs.8185/ha) followed by CP (Rs. 7596/ha), EG (Rs.6021/ha) and NP (Rs.5445/ 
ha). The labour productivity is also higher in CTL (Rs.18134/agricultural worker) followed by CP (Rs. 15760), EG (Rs. 11272) and NP (Rs. 9290) with state average at Rs. 13779. CTL improved its efficiency from 33 per cent to 46 per cent, CP improved from 5 per cent to 43 per cent, EG improved from 22 per cent to 32 per cent, NP improved its efficiency from 20 per cent to 25 per cent, and over all state average efficiency improved from 28 per cent to 37 per cent between period-I and period-II. It indicates that, even though all regions improved their efficiency, still large gaps exist. There is good scope of increasing efficiency in NP (scope of increasing 75\% efficiency) and EGs (scope of increasing 68\% efficiency) compared to only 54 per cent improvement in CTL and 57 per cent improvement in CP region given their low efficiency under given socio-economic and agro-climatic conditions.

Table 11

Trends in Efficiency and Productivity Indices

\begin{tabular}{llrrr}
\hline Region & Period & $\begin{array}{r}\text { Land productivity } \\
(\text { Rs./ha })\end{array}$ & $\begin{array}{r}\text { Labour productivity } \\
(\text { Rs./agril. worker })\end{array}$ & $\begin{array}{r}\text { Efficiency estimates from } \\
\text { B\&C 1995 model (\%) }\end{array}$ \\
\hline \multirow{2}{*}{ CP } & $1971-1990$ & 6153 & 16500 & 35 \\
& $1991-2008$ & 7596 & 15760 & 43 \\
CTL & $1971-1990$ & 6004 & 16216 & 33 \\
& $1991-2008$ & 8185 & 18134 & 46 \\
NP & $1971-1990$ & 4542 & 9419 & 20 \\
& $1991-2008$ & 5445 & 9290 & 25 \\
EG & $1971-1990$ & 4266 & 9775 & 22 \\
& $1991-2008$ & 6021 & 11272 & 32 \\
\multirow{2}{*}{ Orissa } & $1971-1990$ & 5311 & 13248 & 28 \\
& $1991-2008$ & 6872 & 13779 & 37 \\
\hline
\end{tabular}

Source: Statistical Abstracts, Orissa

\section{Inter-district variations}

Inter-district variations in productivity of food grains shows that, it ranges from the highest $1949 \mathrm{~kg} / \mathrm{ha}$ in Sambalpur to the lowest $1214 \mathrm{~kg} / \mathrm{ha}$ in Kalahandi during TE 2008 (Table 12). Per cent share of irrigated area to GCA is the highest for Baleswar (54\%) and the lowest for Kendujar and Phulbani with 24 per cent. The districts, Baleswar and Sambalpur are ranked the highest in fertilizer consumption ( $\mathrm{kg} / \mathrm{ha}$ of GCA) with $99 \mathrm{~kg} / \mathrm{ha}$ and $77 \mathrm{~kg} / \mathrm{ha}$ respectively. While districts Dhenkanal and Phulbani are ranked the lowest with $22 \mathrm{~kg} / \mathrm{ha}$ and $21 \mathrm{~kg} / \mathrm{ha}$. In credit disbursal Baleswar (Rs.5338/ha of GCA) and Dhenkanal (Rs.4379/ha) stand first, while Kalahandi (Rs.1334/ha) and Phulbani (Rs.1172/ha) ranked the least. Cuttack, Puri and Baleswar are three CP districts ranked the highest in rural literacy rate, while Koraput, Kalahandi and Mayurbhanj were ranked the lowest. A careful analysis of the data for different districts reveals that the four CP districts (Balasore, Cuttack, Puri and Ganjam) and two districts (Sambalpur and Bolangir) of CTL region are agriculturally more advanced than other districts. The agricultural success of four CP districts is due to well-developed irrigation facilities with higher doses of fertilizer consumption, high literacy rates and infrastructure. Districts of NP region namely Mayurbhanj, Keonjhar and Sundergarh, and Koraput of EG are found to be the most backward districts. A significant proportion of cropped area in these districts is under rainfed agriculture with frequent droughts and low cropping intensity. Phulbani of EG is the only district with declining agricultural development index over the study period. 
Table 12

District Wise Indices of Agriculture in TE 2008

\begin{tabular}{lcrrrrrr}
\hline $\begin{array}{l}\text { Region/ } \\
\text { district }\end{array}$ & Food grain & $\begin{array}{r}\text { Cropping } \\
\text { Intensity }(\%)\end{array}$ & $\begin{array}{r}\text { Fertilizer/ha } \\
(\mathrm{kg} / \mathrm{ha})\end{array}$ & $\begin{array}{r}\text { Rainfall } \\
(\mathrm{mm})\end{array}$ & $\begin{array}{r}\text { \% irrigated } \\
\text { area }\end{array}$ & $\begin{array}{r}\text { Credit } \\
(\text { Rs./ha })\end{array}$ & $\begin{array}{r}\text { \% rural } \\
\text { Literacy }\end{array}$ \\
\hline CP & 1654 & 143 & 99 & 1203 & 54 & 5338 & 48 \\
Baleswar & 1597 & 187 & 42 & 1372 & 47 & 3539 & 52 \\
Cuttack & 1576 & 187 & 44 & 1044 & 42 & 3587 & 51 \\
Puri & 1898 & 184 & 45 & 1150 & 38 & 3458 & 33 \\
Ganjam & & & & & & & \\
CTL & 1745 & 151 & 32 & 862 & 28 & 1532 & 31 \\
Bolangir & 1949 & 148 & 77 & 1059 & 39 & 3203 & 38 \\
Sambalpur & 1515 & 168 & 22 & 1090 & 25 & 4379 & 42 \\
Dhenkanal & & & & & & & \\
NP & 1580 & 129 & 37 & 1029 & 29 & 1885 & 29 \\
Mayurbhanj & 1485 & 150 & 28 & 1006 & 24 & 1965 & 35 \\
Kendujhar & 1265 & 125 & 24 & 1090 & 26 & 2626 & 34 \\
Sundargarh & & & & & & & \\
EG & 1539 & 153 & 38 & 1151 & 29 & 1581 & 14 \\
Koraput & 1214 & 161 & 45 & 1051 & 33 & 1334 & 24 \\
Kalahandi & 1497 & 163 & 21 & 1043 & 24 & 1172 & 30 \\
Phulbani & 1610 & 159 & 45 & 1088 & 35 & 2783 & 35 \\
Orissa & & & & & & \\
\hline
\end{tabular}

Source: Statistical Abstracts, Orissa

\section{Scope from crop diversification towards high value crops}

In the Battese and Coelli model, both the dependent and independent variables are in log form, regression coefficients reveal elasticities i.e., per cent change in GVAP for a 1 per cent change in independent variables. Given the high proportion of area under water intensive paddy, and need for judicious use of water with the cultivation of irrigated dry crops like pulses, oilseeds and other HVCs which increase land productivity through cropping intensity, estimates of marginal effects due to shift in area from paddy to pulses, oilseeds and other HVCs are estimated and presented in Table 13. On average, shift of 1 hectare of area from paddy to pulses, oilseeds and HVCs resulting in an increase of GVAP by Rs.6220/ha, Rs.5990/ha and Rs.50430/ha respectively at state level. At district level, shift of area to pulses in Balasore, Mayurbhanj and Sambalpur gives higher returns per unit area; while shift to oilseeds generate more returns in Cuttack, Kalahandi, Keonjar and Puri districts. Shift to HVCs may result in higher increase of gross returns in Bolangir, Mayurbhanj and Sambalpur districts. The return is huge, given the average gross returns/ha in the state is only Rs 11000/ha and more than 50 per cent of cropped area is under paddy. However, it requires development of drainage facilities as about 70 per cent of area in Orissa is submerged frequently due to high incidence of flooding. Supply of inputs like improved seed, fertilizer, credit and development of markets are essential for growing HVCs like fruits and vegetables and sugarcane. In focus group interviews local sugarcane farmers expressed that the local sugar factories were closed down due to uncertain supply and production of raw material (cane) since a decade and many more sugar factories are planning to windup. 
Table 13

Increase in GVAP (Rs/ha) from Crop Diversification from Paddy at 2004/5 Prices

\begin{tabular}{|c|c|c|c|c|c|c|c|}
\hline \multirow[t]{2}{*}{ Crop } & \multicolumn{4}{|c|}{$C P$} & \multicolumn{3}{|c|}{$C T L$} \\
\hline & Bolangir & Cuttack & Ganjam & Puri & Balasore & Dhenkanal & Sambalpur \\
\hline Pulses & 6920 & 5140 & 4210 & 5650 & 11710 & 4710 & 12040 \\
\hline Oilseeds & 3890 & 10650 & 7190 & 10640 & 9500 & 5430 & 3650 \\
\hline \multirow[t]{3}{*}{ HVCs } & 123250 & 58560 & 58110 & 64520 & 22520 & 48680 & 145600 \\
\hline & \multicolumn{3}{|c|}{$E G$} & \multicolumn{3}{|c|}{$N P$} & Orissa \\
\hline & Kalahandi & Koraput & Phulbani & Keonjhar & & Sundergarh & \\
\hline Pulses & 3660 & 8160 & 4000 & 6380 & 10140 & 6710 & 6220 \\
\hline Oilseeds & 14880 & 4020 & 3470 & 15640 & 9120 & 4790 & 5990 \\
\hline HVCs & 16960 & 82320 & 26740 & 88030 & 224750 & 63650 & 50430 \\
\hline
\end{tabular}

Note: estimates of marginal increase in gross revenue are based on elasticity of gross revenue for pulses, oilseeds and other HVCs are estimated as $0.19,0.12$ and 0.06 .

District level productivity indices are given in table 14. In terms of land productivity Cuttack, Dhenkanal and Ganjam are top three districts, while in terms of labour productivity Dhenkanal, Puri and Cuttack are top three districts belongs to CTL and CP. While, in land productivity bottom three districts are Surendergarh, Keonjhar and Phulbani and in labour productivity bottom three districts are Koraput, Mayurbhani and Koenjhar. Most of the districts of CP and CTL were showed higher efficiency, while districts of EG and NP showed the lower efficiency. Cuttack, Sambalpur, Dhenkanal are top three districts, while Surendergarh, Keonjhar and Phulbani are bottom three districts in terms of efficiency.

Table 14

District Wise Estimates of Efficiency and Productivity Indices (mean 1971-2008)

\begin{tabular}{|c|c|c|c|c|}
\hline Region & District & $\begin{array}{r}\text { Labour Productivity } \\
\text { (Rs/labour) }\end{array}$ & $\begin{array}{r}\text { Land productivity } \\
(\text { Rs/ha) }\end{array}$ & $\begin{array}{r}\text { Efficiency } \\
(\%)\end{array}$ \\
\hline \multirow{4}{*}{$\mathrm{CP}$} & Bolangir & 12469 & 6051 & 30 \\
\hline & Cuttack & 20992 & 7489 & 47 \\
\hline & Ganjam & 10455 & 6730 & 38 \\
\hline & Puri & 20866 & 6717 & 39 \\
\hline \multirow{3}{*}{ CTL } & Balasore & 13845 & 5937 & 32 \\
\hline & Dhenkanal & 21415 & 7096 & 41 \\
\hline & Sambalpur & 15756 & 7674 & 43 \\
\hline \multirow{3}{*}{ NP } & Keonjhar & 9540 & 4593 & 21 \\
\hline & Mayurbhanj & 8295 & 5287 & 24 \\
\hline & Surendergarh & 10264 & 4862 & 22 \\
\hline \multirow{3}{*}{ EG } & Kalahandi & 12554 & 5866 & 30 \\
\hline & Koraput & 7827 & 4424 & 29 \\
\hline & Phulbani & 10793 & 4677 & 20 \\
\hline
\end{tabular}

Source: Statistical Abstracts, Orissa

\section{Low Productive Kharif Paddy and Options for Crop Diversification}

The area under paddy during kharif season is about 4.12 mha and during rabi 0.33 mha in 2008 (Table 15). Kharif paddy occupy 93 per cent of total paddy area in the state with $58 \%$ of area under rainfed, hence suffering from low productivity $(1658 \mathrm{~kg} / \mathrm{ha}$ as against $2393 \mathrm{~kg} /$ 
ha in rabi) with higher variability (Coefficient of variation for kharif paddy is $24 \%$ against 7 $\%$ for rabi paddy) in productivity. Whereas, rabi paddy suffers from higher variability in area sown (21.6\% as against $1.3 \%$ in kharif area) due to uncertain irrigated area. Further, there is stagnation in area under rabi paddy i.e., area is hovering between 0.14 million ha in 1971 to 0.33 million ha in 2008. As the rabi-paddy productivity is much higher, options to increase area under rabi- paddy, coupled with replacement of low productive kahrif paddy area with rainfed or irrigated-dry crops like pulses and oilseeds needs to be explored.

Table 15

Season wise Paddy Production Scenario

\begin{tabular}{|c|c|c|c|c|c|c|}
\hline \multirow[t]{2}{*}{ Year } & \multicolumn{2}{|c|}{ area $(m h a)$} & \multicolumn{2}{|c|}{ Production (mt) } & \multicolumn{2}{|c|}{ productivity $(\mathrm{kg} / \mathrm{ha})$} \\
\hline & kharif & rabi & kharif & rabi & kharif & $r a b i$ \\
\hline 1971 & 4.33 & 0.14 & 3.91 & 0.19 & 902 & 1387 \\
\hline 1991 & 4.19 & 0.21 & 4.84 & 0.43 & 1156 & 2019 \\
\hline 2008 & 4.12 & 0.33 & 6.83 & 0.79 & 1658 & 2393 \\
\hline $\mathrm{CV} \%$ & 1.3 & 21.6 & 24.1 & 25.6 & 24.2 & 7.1 \\
\hline
\end{tabular}

Source: Statistical Abstracts, Orissa

In Orissa, Kharif Paddy is grown on all types of lands irrespective of its suitability. Paddy grown on high-lands under rainfed conditions is most vulnerable to moisture stress, leading to drastic productivity reduction in years of poor rainfall. It is therefore necessary to diversify this area. The extent of high land paddy in the state is about 1.03 million ha (Table 16). Diversification from paddy to the above crops to be done in CTL, EGs and NP regions, as productivity of paddy in these regions is low and higher water scarcity. Since most of the small farmers who cultivate the high lands prefer to grow paddy for reasons of food security, partial substitution of paddy with alley cropping (Mixed cropping) is considered to be more appropriate measure to achieve the crop diversification. Generally farmers practice single crop per year with mixed farming practices like Paddy+Arhar(41\% of mixed crop area), Arhar+Mung(23\%), Arhar+Groundnut(20\%), Ragi+Arhar(4\%), Maize+Arhar(3\%), Maize+Cowpea(2\%) etc. The steps are also to be taken to produce and distribute improved seeds of early-type varieties of paddy along with seeds of pulses, oilseeds and fruits and vegetable seeds.

Table 16

Proposed Crop Diversification Plan in Orissa (2007/08)

\begin{tabular}{lccc}
\hline Diversification from & $\%$ & diversification to & $\%$ \\
\hline rice fallow land (with pulses, oilseeds) & 37.7 & Pulses & 34.6 \\
Diversion from high land paddy & 19.5 & Vegetables & 18.9 \\
Drought affected medium land paddy & 17.5 & Cereals & 14.8 \\
Aromatic Rice & 15.6 & Oilseeds & 13.9 \\
Saline inundated area & 3.3 & Fibres & 6.7 \\
Sand Dune & 2.9 & Sugarcane & 6.4 \\
Rice Fish Culture & 1.9 & Horticultural & 2.4 \\
minor millets & 1.6 & Spices & 2.3 \\
Total area (1.03 million ha) & 100 & Total & 100 \\
\hline
\end{tabular}

Source: Statistical Abstracts, Orissa 


\section{Policy Options for Improving Efficiency of Orissa Agricultural Sector}

Orissa is one of the poorest states in India with about 85 per cent of population lives in rural areas mostly dependent on agriculture. Over the last three decades (1971-2008) there has been stagnation in crop production in Orissa with low-input and low-output vicious cycle dominated by only paddy cultivation. Paddy occupies 50 per cent of gross cropped area and contributes to 54 per cent to Gross Value of Agricultural Production (GVAP). The area under pulses is 22 per cent (19\% of GVAP), while area under oilseeds is about 9 per cent (with $13 \%$ share in GVAP) and area under other crops which include sugarcane, fruits and vegetables is 13 per cent (in value terms contributes only 10\%). However, cost of production of pulses, oilseeds and other crops are low compared to paddy, hence net returns per hectare to economy and to the farmers are high compared to paddy (Reddy, 2009a; Reddy, 2009b, Reddy et al., 2011, Reddy 2010b). To enhance district level GVAP, Orissa needs to diversify its crop sector towards pulses, oilseeds and HVCs through creation/development of enabling factors like certified seed, credit, fertilizers, drainage facilities, supplementary irrigation and infrastructure for marketing, which also increases farmers income (Reddy, 2004). The growth rate of vital inputs like seed replacement ratio, fertilizer and energy use is slow and less than all-India, which needs to be improved (Orissa Agricultural Statistics, 2011). Literacy rate, irrigation, marketing infrastructure and transport facilities are crucial for increasing GVAP at district level, as the level of these inputs are not even reached to a threshold level to significantly influence productivity levels (Reddy and Kumar, 2006). District level average efficiency is very low (only 37 per cent). This indicates that with the existing resources and technology and given agro-climatic conditions, an average district can enhance GVAP by another 64\%. It is important that, all these inputs should be supplied to the farmers under one roof, so that transaction costs to farmers can be minimized. Within state, there is significant regional differences, mainly Coastal Plain and Central Table Land regions are endowed with good natural resources, hence efficiency, land and labour productivity is higher and stable than other two regions Northern Plateau and Eastern Ghats which are less resource endowed. However, there is slow progress in efficiency and productivity during 1991-2008 over 1971-1990 in all the regions. In the successive five year plan (2002-07) very little funds are devoted to agricultural sector (2.18\%) compared to irrigation and flood control (22\%), special area program (13\%), social services $(26 \%)$. There is a greater need to directly focus on agricultural sector with more funds with the following objectives (i) drought proofing, (ii) improved agricultural productivity through crop diversification to pulses, oilseeds and other high value crops and (iii) improved quality input and output markets like credit/banking facilities, seed production and distribution at local markets, policies to increased use of fertilizer, electricity and technology in backward regions like EG, NP and CTL. In order to achieve these objectives, the following strategies seem appropriate: Building rural productive infrastructure (e.g., roads, bridges, drainage and irrigation projects, tanks, watershed development, markets and warehouses) (Reddy, 2011). Agricultural development on sustainable basis for transforming low-input-low-output agriculture to high-input-high-output agricultural sector especially in backward regions like Eastern Ghats and Northern Plateau (e.g., productive rural infrastructure, agriculture development programs, seed production and distribution and micro-credit support, targeting scheduled tribes and castes). Interventionist policies by removing barriers to factor mobility and ensuring minimum standards in basic services across the state will reduce regional disparities (Shankar R and A Shah, 2003). 


\section{References}

Annual Statistical Abstracts (2011), Directorate of Economics and Statistics, Various states

Audirac, Ivonne (ed.) 1997. Rural Sustainable Development in America. John Wiley and Sons.

Battese, G.E., and T.J. Coelli (1995) A Model for Technical Inefficiency Effects in a Stochastic Frontier Production Function for Panel Data. Empirical Economics, 20, 325-332.

Datt, G. and M. Ravallion (1996). "How Important to India's Poor is the Sectoral Composition of Economic Growth?" The World Bank Economic Review 10(1): 1-25.

Kurian NJ (2000) Widening Regional Disparities in India: Some Indicators, Economic and Political Weekly Vol. 35, No. 7 (Feb. 12-18, 2000), pp. 538-550

Mishra, S (2009) Poverty and Agrarian Distress in Orissa, Indira Gandhi Institute of Development Research, Mumbai September 2009 http://www.igidr.ac.in/pdf/publication/WP-2009-006.pdf

Myrdal, G (1957) Economic Theory and Under-developed Regions. London: Duck-worth

Orissa Agricultural Statistics (2011), Directorate of Agricultural and Food Production, Orissa, Bhubaneswar, various issues.

Orissa Development Report (2004) Planning Commission, Government of India, Yojana Bhawan, New Delhi.

Pingali, P.L., and P.W. Heisey (2003) Cereal Crop Productivity in Developing Countries. CIMMYT Economics Paper 99-03. Mexico D.F.: CIMMYT.

Reddy A A (2004). Consumption Pattern, Trade and Production Potential of Pulses, Economic and Political Weekly, Vol.39 (44) pp.4854-4860, 2004.

Reddy A A (2006). Productivity Growth in Regional Rural Banks, Economic and Political Weekly, Vol.XLI, No.11, March 18, 2006 pp. 1079-1086.

Reddy AA (2009a). Pulses Production Technology: Status and Way Forward, Economic and Political Weekly, Vol. 44, No. 52, pp. 73-80, December 2009

Reddy AA (2009b). Policy Options for India's Edible Oil Complex, Economic and Political Weekly, Vol. 44, No. 4, pp. 22-24, 2009

Reddy AA (2010a). Regional Disparities in Food Habits and Nutritional Intake in Andhra Pradesh, India, Regional and Sectoral Economic Studies, Vol. 10-2 (2010) 125-134

Reddy AA and P. Kumar (2006) Occupational Diversification of Households in Rural Andhra Pradesh, Journal of Indian School of Political Economy, Jan-June, 2006, Pp. 77-91

Reddy AA, Ch. Radhika Rani and GP Reddy (2011). Policy Options for Edible Oil Complex in India under WTO Regime, Journal of Rural Development, Vol. 30. No. (1) p. 11-24.

Reddy, AA (2009c) Research Report on Factor Productivity and Marketed Surplus of Major Crops in India: Analysis of Orissa State, Planning Commission, Government of India.

Reddy, AA (2010b). Disparities in Agricultural Productivity Growth in Andhra Pradesh, Indian Economic Journal, Vol. 58, No. 1, April-June 2010. Pp. 134-154

Reddy, AA (2011) Dynamics of the Agricultural Economy of Andhra Pradesh, India since the Last Five Decades, Journal of Development and Agricultural Economics Vol. 3(8), pp. 394-410, August 2011

Shankar R and A Shah (2003) Bridging the Economic Divide Within Countries: A Scorecard on the Performance of Regional Policies in Reducing Regional Income Disparities, World Development Vol. 31, No. 8, pp. 1421-1441, 2003

Williamson J.G. (1965) Regional Inequality and The Process of National Development: A Description of the Patterns, Economic and Cultural Change, 13, 1-84. 